\title{
OPTIMAL CONTROL OF SOLUTIONS TO THE INITIAL-FINAL PROBLEM FOR THE MODEL OF LINEAR WAVES IN A PLASMA
}

\author{
A.A. Zamyshlyaeva, O.N. Tsyplenkova \\ South Ural State University, Chelyabinsk, Russian Federation \\ E-mail: zamyshliaevaaa@susu.ru
}

The optimal control problem for a Sobolev type equation of higher order with a relatively polynomially bounded operator pencil is investigated in the paper. The results are applied to the study of the optimal control of solutions to the initial-final problem for the model of linear waves in plasma. The first results on the investigation of equation that describes the linear ion-acoustic waves in an unmagnetized plasma and on the study of some properties of these waves were obtained by Yu.D. Pletner. The initial-final conditions posed for the fourth-order Sobolev type equation are the generalization of the conditions in the Cauchy problem that is unsolvable at the arbitrary initial values. The research is based on the phase space method developed by G.A. Sviridiuk and the theory of relatively polynomially bounded operator pencil developed by A.A. Zamyshlyaeva. The article considers an equation that describes ion-acoustic waves in a plasma in an external magnetic field.

Keywords: Sobolev type equations of higher order with a relatively polynomially bounded operator pencil; model of linear waves in a plasma; optimal control problem; initial-final conditions.

\section{Introduction}

Let $\Omega=(0, a) \times(0, b) \times(0, c) \subset R^{3}$. The article investigates the optimal control of solutions to the following problem:

$$
\begin{gathered}
(\lambda-\Delta) x_{t t t t}(s, t)=\left(\Delta-\lambda^{\prime}\right) x_{t t}(s, t)+\alpha \frac{\partial^{2} x(s, t)}{\partial s_{3}^{2}}+u(s, t), s \in \Omega, t \in(0, \tau), \\
x(s, t)=0, \quad(s, t) \in \partial \Omega \times(0, \tau) .
\end{gathered}
$$

Model (1), (2) describes ion-acoustic waves in plasma in an external magnetic field [1]. The parameters in equation (1) relate such physical quantities as the ionic hydro frequency, the Langmuir frequency, and the Debye radius. The function $x(s, t)$ represents the generalized potential of an electric field, the function $u(s, t)$ represents an external effect.

Problem (1), (2) is investigated in the framework of the theory of relatively polynomially bounded pencils of operators [2]. Consider a high-order abstract Sobolev type equation

$$
A x^{(n)}=B_{n-1} x^{(n-1)}+\ldots+B_{0} x+y+C u,
$$

where the operators $A, B_{n-1}, \ldots, B_{0} \in L(X ; Y), C \in L(U ; Y)$, the functions $u:[0, \tau) \subset R_{+} \rightarrow U$, $y:[0, \tau) \subset R_{+} \rightarrow Y(\tau<\infty), X, Y, U$ are Hilbert spaces.

Supplement equation (3) with initial-final conditions [3]

$$
\begin{aligned}
& P_{i n}\left(x^{(k)}(0)-x_{k}^{0}\right)=0, \\
& P_{\text {fin }}\left(x^{(k)}(\tau)-x_{k}^{\tau}\right)=0,
\end{aligned}
$$

where $P_{i n(f i n)}$ are some projectors in space $X$. Thus, the optimal control problem is to find a pair $(\hat{x}, \hat{u})$, where $\hat{x}$ is a solution of (1), (2), and $\hat{u} \in U_{a d}$ is the control for which the relation

$$
J(\hat{x}, \hat{u})=\min _{(x, u) \in X \times U_{a d}} J(x, u)
$$

holds.

Here $J(x, u)$ is some specially constructed penalty functional, and $U_{a d}$ is a closed convex set in the space of controls $U$. 
Many non-classical models of mathematical physics [4-9] are based on Sobolev type equations. For example, they occur in problems of hydromechanics, plasma physics, atmospheric physics, filtration theory, theory of electrical circuits, and others. In the work, to find the optimal control of solutions to linear Sobolev type equations of high-order, the ideas and methods obtained by G.A. Sviridyuk [10] and his students [11-13] in the study of first-order Sobolev type equations are used. Here the initial-final problem [14] is investigated. A distinctive feature of this problem is that one projection of the solution is specified at the initial moment of time, and the other at the final point. The initial-final problem for the first-order Sobolev type equations was considered by G.A. Sviridyuk and S.A. Zagrebina.

\section{Polynomially $A$-bounded operator pencils and projectors. Strong solutions}

By $\vec{B}$ denote the pencil formed by operators $B_{n-1}, \ldots, B_{0}$. The sets $\rho^{A}(\vec{B})=\left\{\mu \in C:\left(\mu^{n} A-\right.\right.$ $\left.\left.-\mu^{n-1} B_{n-1}-\ldots-\mu B_{1}-B_{0}\right)^{-1} \in L(Y ; X)\right\}$ and $\sigma^{A}(\vec{B})=C \backslash \rho^{A}(\vec{B})$ are called an $A$ - resolvent set and an $A$-spectrum of pencil $\vec{B}, \quad$ respectively. The operator function $R_{\mu}^{A}(\vec{B})=\left(\mu^{n} A-\mu^{n-1} B_{n-1}-\ldots-\mu B_{1}-B_{0}\right)^{-1}$ of a complex variable with domain $\rho^{A}(\vec{B})$ is called an $A-$ resolvent of pencil $\vec{B}$.

Let the pencil be $\vec{B}$ polynomially $A$-bounded. Introduce an additional condition [15]

$$
\int_{\gamma} \mu^{k} R_{\mu}^{A}(\vec{B}) d \mu \equiv 0, \quad k=\overline{0, n-2},
$$

where $\gamma$ is a contour that bounds the domain containing the relative spectrum of the pencil $\vec{B}$. Then the operators

$$
P=\frac{1}{2 \pi i} \int_{\gamma} R_{\mu}^{A}(\vec{B}) \mu^{n-1} A d \mu, \quad Q=\frac{1}{2 \pi i} \int_{\gamma} \mu^{n-1} A R_{\mu}^{A}(\vec{B}) d \mu
$$

are projectors in spaces $X$ and $Y$. Denote $X^{0}=\operatorname{ker} P, Y^{0}=\operatorname{ker} Q, X^{1}=\operatorname{im} P$ and $Y^{1}=\operatorname{im} Q$. If the pencil of operators is polynomially $A$-bounded, $\infty$ is a pole of order $p \in\{0\} \bigcup N$ of the $A$-resolvent of pencil $\vec{B}$, then the pencil of operators $\vec{B}$ is called $(A, p)$-bounded.

Let the pencil $\vec{B}$ be polynomially $A$-bounded, (6) hold and the following conditions be satisfied:

$$
\begin{gathered}
\sigma^{A}(\vec{B})=\sigma_{0}^{A}(\vec{B}) \cup \sigma_{1}^{A}(\vec{B}), \sigma_{k}^{A}(\vec{B}) \neq \varnothing, k=\overline{0,1} ; \\
\text { and there is a circuit } \gamma_{0} \subset C, \\
\text { bounding the domain } \Gamma_{0} \subset C \text { such, that } \\
\Gamma_{0} \cap \sigma_{0}^{A}(\vec{B})=\sigma_{0}^{A}(\vec{B}), \bar{\Gamma}_{0} \cap \sigma_{1}^{A}(\vec{B})=\varnothing . \\
\int_{\gamma_{0}} \mu^{m} R_{\mu}^{A}(\vec{B}) d \mu \equiv 0, m=\overline{0, n-2 .}
\end{gathered}
$$

Operators

$$
P_{f i n}=\frac{1}{2 \pi i} \int_{\gamma_{0}} \mu R_{\mu}^{A}(\vec{B}) A d \mu \in L(X)
$$

and $P_{i n}=P-P_{f i n} \in L(X)$ are projectors in space $X[15]$.

Definition 1. The vector-function $x \in H^{n}(X)=\left\{x \in L_{2}(0, \tau ; X): x^{(n)} \in L_{2}(0, \tau ; X)\right\}$ is called a strong solution of linear non homogeneous Sobolev type equation

$$
A x^{(n)}=B_{n-1} x^{(n-1)}+\ldots+B_{0} x+y,
$$

if it turns the equation to an identity almost everywhere on interval $(0, \tau)$. A strong solution $x=x(t)$ of (9) is called a strong solution to (4), (9), if (4) holds.

Theorem 1. If the pencil $\vec{B}$ is $(A, p)$-bounded, $p \in\{0\} \bigcup N$, conditions (6)-(8) are satisfied, then for arbitrary $x_{k}^{0}, x_{k}^{\tau} \in X, k=\overline{0, n-1}$ and $y \in H^{p+n}(Y)$ there exists a unique strong solution to (4) for equation (9). 


\section{Математика}

\section{Optimal control for the model of linear waves in plazma}

Consider problem (4) for equation (3), where the functions $x, y, u$ lie in $X, Y$ and $U$, respectively.

Introduce the control space

$$
\stackrel{\circ}{H}^{p+n}(U)=\left\{u \in L_{2}(0, \tau ; U): u^{(p+n)} \in L_{2}(0, \tau ; U), u^{(q)}(0)=0, q=\overline{0, p}\right\},
$$

$p \in\{0\} \cup N$. It is a Hilbert space with inner product

$$
[v, w]=\sum_{q=0}^{p+n} \int_{0}^{\tau}\left\langle v^{(q)}, w^{(q)}\right\rangle_{U} d t
$$

In the space $\stackrel{\circ}{H}^{p+n}(U)$ single out a closed convex subset $U_{a d}$. A vector function $\hat{u} \in U_{a d}$ is called an optimal control of solutions to (3), (4), if (5) holds.

Let us prove the existence of optimal control $\hat{u} \in U_{a d}$, minimizing penalty functional

$$
J(x, u)=\mu \sum_{q=0}^{n} \int_{0}^{\tau}\left\|x^{(q)}-\tilde{x}^{(q)}\right\|^{2} d t+v \sum_{q=0}^{p+n} \int_{0}^{\tau}\left\langle N_{q} u^{(q)}, u^{(q)}\right\rangle_{U} d t .
$$

Here $\mu, v>0, \mu+v=1, \quad N_{q} \in L(U), q=0,1, \ldots, p+n$, are self-adjoint positively defined operators, and $\tilde{x}(t)$ is the target state of the system.

Theorem 2. If the pencil $\vec{B}$ is polynomially $A$-bounded, conditions (6)-(8) are satisfied, then for arbitrary $x_{k}^{0}, x_{k}^{\tau} \in X, k=\overline{0, n-1}$ and $y \in H^{p+n}(Y)$ there exists a unique optimal control of solutions to problem (3), (4).

Reducing problem (1), (2) to equation (3) put

$$
X=\left\{x \in W_{2}^{l+2}(\Omega): x(s)=0, s \in \partial \Omega\right\}, \quad Y=W_{2}^{l}(\Omega),
$$

where $W_{2}^{l}(\Omega)$ are Sobolev spaces. Define the operators $A=\lambda-\Delta, \quad B_{2}=\Delta-\lambda^{\prime}, \quad B_{0}=\alpha \frac{\partial^{2}}{\partial x_{3}^{2}}$, $B_{3}=B_{1}=O$. Operators $A, B_{3}, B_{2}, B_{1}, B_{0} \in L(X ; Y)$ for all $l \in\{0\} \bigcup N$.

Denote by $\varphi_{i j k}=\left\{\sin \frac{\pi i s_{1}}{a} \sin \frac{\pi j s_{2}}{b} \sin \frac{\pi k s_{3}}{c}\right\}$ the eigenfunctions of the Dirichlet problem for the Laplace operator, where $i, j, k \in N$, and the corresponding eigenvalues are denoted by $\lambda_{i j k}=-\sqrt{\left(\frac{\pi i}{a}\right)^{2}+\left(\frac{\pi j}{b}\right)^{2}+\left(\frac{\pi k}{c}\right)^{2}}$.

Since $\left\{\varphi_{i j k}\right\} \subset C^{\infty}(\Omega)$, then we get

$$
\mu^{4} A-\mu^{3} B_{3}-\mu^{2} B_{2}-\mu B_{1}-B_{0}=\sum_{i, j, k=1}^{\infty}\left[\left(\lambda-\lambda_{i j k}\right) \mu^{4}+\left(\lambda^{\prime}-\lambda_{i j k}\right) \mu^{2}-\alpha\left(\frac{\pi k}{c}\right)^{2}\right]<\varphi_{i j k}, \cdot>\varphi_{i j k},
$$

where $\langle,, \cdot\rangle$ is an inner product in $L^{2}(\Omega)$.

Lemma 1. [15] Let one of the following conditions be satisfied:

(i) $\lambda \notin \sigma(\Delta)$;

(ii) $(\lambda \in \sigma(\Delta)) \wedge\left(\lambda \neq \lambda^{\prime}\right)$.

Then the pencil $\vec{B}$ is polynomially $(A, 0)$-bounded, and conditions (6) are fulfilled.

The $A$-spectrum of the pencil $\vec{B}$ consists of solutions $\mu_{i j k}^{l}, l=\overline{1,4}$ of equation

$$
\left(\lambda_{i j k}-\lambda\right) \mu^{4}+\left(\lambda_{i j k}-\lambda^{\prime}\right) \mu^{2}-\alpha\left(\frac{\pi k}{c}\right)^{2}=0
$$

Construct the projector 


$$
P=\left\{\begin{array}{c}
I, \text { if (i) holds, } \\
I-\sum_{\lambda_{i j k}=\lambda}\left\langle\cdot, \varphi_{i j k}\right\rangle \varphi_{i j k}, \text { if (ii) holds. }
\end{array}\right.
$$

To construct the projector $P_{f i n}$ choose a domain $\Gamma_{0} \subset C$, containing, for example, a finite set $\sigma_{0}^{A}(\vec{B})$ of points $\mu_{i j k}^{l}$ of the $A$ - spectrum of the pencil $\vec{B}$ and such that $\partial \Gamma_{0} \cap \sigma_{0}^{A}(\vec{B})=\varnothing$. As it is easy to see, the domain $\Gamma_{0}$ can be chosen such that $\partial \Gamma_{0}=\gamma_{0}$ is a contour. Thus, condition (7) is satisfied.

Consider the initial-final problem

$$
\begin{aligned}
\sum_{\lambda_{i j k} \neq \lambda, \mu_{i j k}^{l} \in \sigma_{1}^{A}(\vec{B})}<x(\cdot, 0)-x_{0}^{0}, \varphi_{i j k}>\varphi_{i j k}=0, & <x_{t}(\cdot, 0)-x_{1}^{0}, \varphi_{i j k}>\varphi_{i j k}=0, \\
\sum_{\lambda_{i j k} \neq \lambda, \mu_{i j k}^{l} \in \sigma_{1}^{A}(\vec{B})}<x_{t t}(\cdot, 0)-x_{2}^{0}, \varphi_{i j k}>\varphi_{i j k}=0, & \sum_{\lambda_{i j k} \neq \lambda, \mu_{i j k}^{l} \in \sigma_{1}^{A}(\vec{B})}<x_{t t t}(\cdot, 0)-x_{3}^{0}, \varphi_{i j k}>\varphi_{i j k}=0, \\
\sum_{\lambda_{i j k} \neq \lambda, \mu_{i j k}^{l} \in \sigma_{1}^{A}(\vec{B})}< & <x(\cdot, \tau)-x_{0}^{\tau}, \varphi_{i j k}>\varphi_{i j k}=0, \\
\sum_{\lambda_{i j k} \neq \lambda, \mu_{i j k}^{l} \in \sigma_{0}^{A}(\vec{B})}< & <x_{t}(\cdot, \tau)-x_{1}^{\tau}, \varphi_{i j k}>\varphi_{i j k}=0, \\
\sum_{\lambda_{i j k} \neq \lambda, \mu_{i j k}^{l} \in \sigma_{0}^{A}(\vec{B})}< & <x_{t t}(\cdot, \tau)-x_{2}^{\tau}, \varphi_{i j k}>\varphi_{i j k}=0, \\
\sum_{\lambda_{i j k} \neq \lambda, \mu_{i j k}^{l} \in \sigma_{0}^{A}(\vec{B})}< & <x_{t t t}(\cdot, \tau)-x_{3}^{\tau}, \varphi_{i j k}>\varphi_{i j k}=0, \\
\sum_{\lambda_{i j k} \neq \lambda, \mu_{i j k}^{l} \in \sigma_{0}^{A}(\vec{B})} &
\end{aligned}
$$

for equation (1) with boundary conditions (2).

Theorem 3. For any $\alpha \in R$ and $\lambda \in R$ such that the conditions of Lemma 1 are fulfilled, and for any $\tau \in R_{+}, x_{k}^{0}, x_{k}^{\tau} \in X, k=\overline{0,3}$, there exists a unique solution to the optimal control problem for equation (1) with conditions (2), (12) that minimizes functional (10).

\section{References}

1. Sveshnikov A.G., Al'shin A.B., Korpusov M.O., Pletner Yu.D. Lineynye i nelineynye uravneniya sobolevskogo tipa (Linear and Nonlinear the Sobolev Type Equations). Moscow, FIZMATLIT Publ., 2007, 736 p. (in Russ.).

2. Zamyshlyaeva A.A. The Higher-Order Sobolev-Type Models. Bulletin of the South Ural State University, Series "Mathematical Modelling, Programming \& Computer Software”, 2014, Vol. 7, no. 2, pp. 5-28. (in Russ.). DOI: 10.14529/mmp140201

3. Sagadeeva M.A., Zagrebina S.A., Manakova N.A. Optimal Control of Solutions of a Multipoint Initial-Finish Problem for Non-Autonomous Evolutionary Sobolev Type Equation. Evolution equations and control theory, 2019, Vol. 8, no. 3, pp. 473-488. DOI: 10.3934/eect.2019023

4. Manakova N.A., Bogatyreva E.A. Mathematical Model of the Start Control of Electric Field Potential in Conducting Medium without Dispersion Considering Relaxation. 2016 2nd International Conference on Industrial Engineering, Applications and Manufacturing (ICIEAM), Chelyabinsk, 2016, pp. 1-5. DOI: 10.1109/ICIEAM.2016.7911711

5. Zamyshlyaeva A.A., Tsyplenkova O.N. Optimal Control of Solutions to the Showalter-Sidorov Problem in a Model of Linear Waves in Plazma. Journal of Computational and Engineering Mathematics, 2018, Vol. 5, no. 4, pp. 46-57. DOI: 10.14529/jcem180404 


\section{Математика}

6. Bogatyreva E.A., Manakova N.A. Numerical Simulation of the Process of Nonequilibrium Counterflow Capillary Imbiition. Computational mathematics and mathematical physics, 2016, Vol. 56, no. 1, pp. 132-139. DOI: 10.1134/S0965542516010085

7. Keller A.V., Ebel A.A. Parallelization of Numerical Algorithm for Optimum Dynamic Measurement Problem Solution. Proc. 2nd International Ural Conference on Measurements (UralCon), Chelyabinsk, 2017, pp. 372-377. DOI: 10.1109/URALCON.2017.8120738

8. Zakirova G.A. Inverse Spectral Problems and Mathematical Models of Continuum Mechanics. Bulletin of the South Ural State University, Series "Mathematical Modelling, Programming \& Computer Software”, 2019, Vol. 12, no. 2, pp. 5-24. DOI: 10.14529/mmp190201

9. Shafranov D.E., Kitaeva O.G. The Barenblatt-Zheltov-Kochina Model with the ShowalterSidorov Condition and Additive "white noise" in Spaces of Differential Forms on Riemannian Manifolds without Boundary. Global and Stochastic Analysis, 2018, Vol. 5, no. 2, pp. 139-152.

10. Sviridyuk G.A., Fedorov V.E. Linear Sobolev Type Equations and Degenerate Semigroups of Operators, VSP, Utrecht-Boston-Köln-Tokyo, 2003, 216 p. DOI: 10.1515/9783110915501

11. Manakova N.A., Svirigyuk G.A. An Optimal Control of the Solutions of the Initial-Final Problem for Linear Sobolev Type Equations with Strongly Relatively $p$-Radial Operator. Semigroup of operators - theory and applications, 2015, pp. 213-224. DOI: 10.1007/978-3-319-12145-1_13

12. Sviridyuk G.A., Efremov A.A. Optimal Control of Sobolev Type Linear Equations with Relatively $p$-Sectorial Operators. Differential Equations, 1995, Vol. 31, no. 11, p. 1882-1890.

13. Zamyshlyaeva A.A., Tsyplenkova O.N., Bychkov E.V. Optimal Control of Solutions to the Showalter-Sidorov Problem for the Sobolev type Equation of Higher Order. Proc. 2nd International Conference on Industrial Engineering, Applications and Manufacturing (ICIEAM), Chelyabinsk, 2016, pp. 1-4. DOI: 10.1109/ICIEAM.2016.7911725

14. Favini A., Zagrebina S.A., Sviridyuk G.A. Multipoint Initial-Final Value Problems for Dynamical Sobolev-type Equations in the Space of Noises. Electronic Journal of Differential Equations, 2018, Vol. 2018, p. 128.

15. Zamyshlyaeva A.A. Lineynye uravneniya sobolevskogo tipa vysokogo poryadka (Linear Sobolev Type Equations of Higher Order). Chelyabinsk, Publishing center of SUSU, 2012, 88 p. (in Russ.).

Received October 5, 2019

Bulletin of the South Ural State University Series "Mathematics. Mechanics. Physics" 2019, vol. 11, no. 4, pp. 26-31

Удк 517.9

DOI: $10.14529 / \mathrm{mmph} 190403$

\section{ОПТИМАЛЬНОЕ УПРАВЛЕНИЕ РЕШЕНИЯМИ НАЧАЛЬНО-КОНЕЧНОЙ ЗАДАЧИ ДЛЯ МОДЕЛИ ЛИНЕЙНЫХ ВОЛН В ПЛАЗМЕ}

\section{А.А. Замышляева, О.Н. Цыпленкова}

Южно-Уральский государственный университет, г. Челябинск, Российская Федерация E-mail: zamyshliaevaaa@susu.ru

В работе исследована задача оптимального управления для уравнения соболевского типа высокого порядка с относительно полиномиально ограниченным пучком операторов. Результаты применены к исследованию оптимального управления решениями начально-конечной задачи для модели линейных волн в плазме. Первые результаты по уравнению, которое описывает линейные ионно-звуковые волны в незамагниченной плазме, и изучению некоторых свойств этих волн были получены Ю.Д. Плетнером. Начально-конечные условия, поставленные для уравнения соболевского типа четвертого порядка, являются обобщением условий в задаче Коши, которые неразрешимы при произвольных начальных значениях. Работа основывается на методе фазового про- 
странства, разработанного Г.А. Свиридюком, и теории относительно полиномиально ограниченных пучков операторов, разработанной А.А. Замышляевой. В статье рассмотрено уравнение, которое описывает ионно-звуковые волны в плазме во внешнем магнитном поле.

Ключевые слова: уравнения соболевского типа высокого порядка с относительно полиномиально ограниченным пучком операторов; модель линейных волн в плазме; оптимальное управление; начально-конечные условия.

\section{Литература}

1. Линейные и нелинейные уравнения соболевского типа / А.Г. Свешников, А.Б. Альшин, М.О. Корпусов, Ю.Д. Плетнер. - М.: ФИЗМАТЛИТ, 2007. - 736 с.

2. Замышляева, А.А. Математические модели соболевского типа высокого порядка / А.А. Замышляева // Вестник ЮУрГУ. Серия: «Математическое моделирование и программирование». - 2014. - Т. 7, № 2. - С. 5-28.

3. Sagadeeva, M.A. Optimal Control of Solutions of a Multipoint Initial-Finish Problem for NonAutonomous Evolutionary Sobolev Type Equation / M.A. Sagadeeva, S.A. Zagrebina, N.A. Manakova // Evolution Equations and Control Theory. - 2019. - Vol. 8, № 3. - P. 473-488.

4. Manakova, N.A. Mathematical Model of the Start Control of Electric Field Potential in Conducting Medium without Dispersion Considering Relaxation / N.A. Manakova, E.A. Bogatyreva // 2016 2nd International Conference on Industrial Engineering, Applications and Manufacturing (ICIEAM). Chelyabinsk, 2016. - P. 1-5.

5. Zamyshlyaeva, A.A. Optimal Control of Solutions to the Showalter-Sidorov Problem in a Model of Linear Waves in Plazma / A.A. Zamyshlyaeva, O.N. Tsyplenkova // Journal of Computational and Engineering Mathematics. - 2018. - Vol. 5, № 4. - P. 46-57.

6. Богатырева, Е.А. Численное моделирование процесса неравновесной противоточной капиллярной пропитки / Е.А. Богатырева, Н.А. Манакова // Журнал вычислительной математики и математической физики. - 2016. - Т. 56, № 1. - С. 125-132.

7. Keller, A.V. Parallelization of Numerical Algorithm for Optimum Dynamic Measurement Problem Solution / A.V. Keller, A.A. Ebel // Proc. 2nd International Ural Conference on Measurements. 2017. - p. 372-377.

8. Zakirova, G.A. Inverse Spectral Problems and Mathematical Models of Continuum Mechanics / G.A. Zakirova // Вестник ЮУрГУ. Серия «Математическое моделирование и програмирование». - 2019. - T. 12, № 2. - C. 5-24.

9. Shafranov, D.E. The Barenblatt-Zheltov-Kochina Model with the Showalter-Sidorov Condition and Additive «white noise» in Spaces of Differential Forms on Riemannian Manifolds without Boundary / D.E. Shafranov, O.G. Kitaeva // Global and Stochastic Analysis. - 2018. - Vol. 5, no. 2. C. $139-152$.

10. Sviridyuk, G.A. Linear Sobolev Type Equations and Degenerate Semigroups of Operators / G.A. Sviridyuk, V.E. Fedorov. - Utrecht; Boston; Köln; Tokyo: VSP, 2003. - 216 p.

11. Manakova, N.A. An Optimal Control of the Solutions of the Initial-Final Problem for Linear Sobolev Type Equations with Strongly Relatively $p$-Radial Operator / N.A. Manakova, G.A. Sviridyuk // Semigroup of Operators - Theory and Applications. - 2015. - P. 213-224.

12. Свиридюк, Г.А. Оптимальное управление линейными уравнениями типа Соболева с относительно $p$-секториальными операторами / Г.А. Свиридюк, А.А. Ефремов // Дифференциальные уравнения. - 1995. - Т. 31, № 11. - С. 1912-1919.

13. Zamyshlyaeva, A.A. Optimal Control of Solutions to the Showalter-Sidorov Problem for the Sobolev Type Equation of Higher Order / A.A. Zamyshlyaeva, O.N. Tsyplenkova, E.V. Bychkov // Proc. 2nd International Conference on Industrial Engineering, Applications and Manufacturing, ICIEAM 2016. - 2016. - P. 1-4.

14. Favini, A. Multipoint Initial-Final Value Problems for Dynamical Sobolev-type Equations in the Space of Noises / A. Favini, S.A. Zagrebina, G.A. Sviridyuk // Electronic Journal of Differential Equations. - 2018. - Vol. 2018. - P. 128.

15. Замышляева, А.А. Линейные уравнения соболевского типа высокого порядка / А.А. Замышляева. - Челябинск: Изд. центр ЮУрГУ, 2012. - 107 с.

Поступила в редакцию 5 октября 20192. 